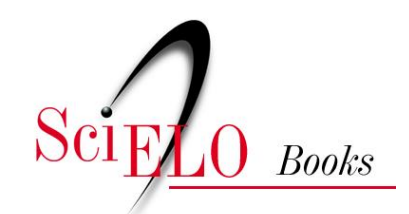

\title{
Da resistência ao texto
}

\author{
Geralda Medeiros Nóbrega
}

\section{SciELO Books / SciELO Livros / SciELO Libros}

NÓBREGA, GM. Da resistência ao texto. In: Hermilo Borba Filho: Memória de resistência e resistência da história [online]. Campina Grande: EDUEPB, 2015, pp. 25-75. ISBN 978-85-7879-334-

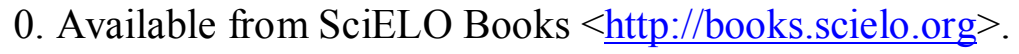

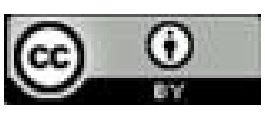

All the contents of this work, except where otherwise noted, is licensed under a Creative Commons Attribution $\underline{4.0 \text { International license. }}$

Todo o conteúdo deste trabalho, exceto quando houver ressalva, é publicado sob a licença Creative Commons Atribição 4.0.

Todo el contenido de esta obra, excepto donde se indique lo contrario, está bajo licencia de la licencia $\underline{\text { Creative }}$ Commons Reconocimento 4.0. 


\title{
DA RESISTÊNCIA AO TEXTO
}

\author{
"[...] em fases apocalípticas o artista \\ se deveria colocar a serviço daquele \\ que sofre, pois de que outras armas \\ poderia ele dispor?"
}

Hermilo Borba Filho

Uma leitura da ficção hermiliana coloca o leitor frente a um projeto literário que reflete um projeto de vida. O compromisso de Borba Filho com uma cultura de resistência, encarada sob aspectos, que não se excluem, porque se complementam, tonificam a escritura do autor, para quem a morada ideal do Diabo é o Nordeste, "pela abundância dos males que aqui existem, traduzidos em latifúndio, doença, marginalização dos pobres, morte inglória, almas cativas" (BORBA FILHO, 1975, p.10). E estes males norteiam toda a sua obra, suas narrativas curtas, sua ficção romanesca, o seu teatro.

Os temas desenvolvidos por este autor funcionam como representação de uma realidade prenhe de toda sorte de injustiças, expressas através de uma ficção em que permeia o fantástico e o maravilhoso, que o autor pernambucano denomina de realismo mágico: "Por outro lado, procuro recriar o Nordeste, num realismo mágico que, transfigurando seres e coisas, dê a medida exata de tudo o que aqui nos envolve." (BORBA FILHO, 1974, p.9). Fazendo uso do realismo mágico, o autor representa a denúncia e a crítica, sendo que a saída de cena 
do realismo faz aflorar a entrada do mágico, num jogo escritural que expressa a "visão de mundo" do autor. Em entrevista, Borba Filho explicita o realismo mágico desenvolvido em sua ficção. É também a sua maneira de representar o Nordeste:

Agora, neste meu Nordeste da Zona da Mata Sul,
as pessoas ressuscitam, traem, castigam e são cas-
tigadas, enchem-se de amores loucos e obsessões,
formam uma frenética procissão com os vícios mais
cultivados do nosso tempo. Há umas pessoas que
levitam, outras que pairam no ar, outras que atraves-
sam terras voando, há peixes que depois de mortos
voltam a viver, há bois misteriosos, rãs gigantescas,
cavalos metade de carne e metade de flandres, mor-
tos convivendo com vivos. E isto é verdade. Basta
prestar atenção (BORBA FILHO, 1974, p. 4).

Situando-se o autor pernambucano no contexto de sua ficção, reconheço que há em Borba Filho um revezamento do mágico e do real, do sonho e da realidade, como uma concepção ora trágica, ora burlesca, como a própria vida, conseguindo "revelar [...] o nonsense de toda ideia e de todo o agir humano" (ARNS, 1980, p.151). E como o nonsense pode ser visto como um vetor de realismo mágico, é preciso deter-se um pouco mais naqueles aspectos que fundamentam os contos hermilianos, o que será feito, de princípio, numa perspectiva de Octavio Ianni. Para este autor, o mágico está presente na literatura e na realidade e "a fantasia do escritor trabalhada por sua linguagem produz a magia da escritura" (IANNI, 1986, p.11), de onde brota um estilo novo, quando a fabulação cria novos meios de expressão, abrindo horizontes para a imaginação. E criatividade é o que não falta às narrativas curtas hermilianas, pois o autor explora crenças, superstições, mitos, folguedos, romanceiro popular, folhetos de cordel, enfim, tudo que tem como motivo a cultura popular. Borba Filho repisa, repete, insiste continuamente nas mesmas ideias e nos mesmos temas, revestindo-os com as 
mesmas palavras, dando a impressão de que o objetivo que tem em mente é canalizá-los para um ponto comum que é o de dissecar todas as variantes da arte popular num método, aparentemente anatômico. Seguindo o pensamento de Ianni (1986, p.14), para quem "o realismo mágico [...] apresenta diversas conotações: maravilhoso, fantástico, barroco, grotesco", pode-se reconhecer que estas mesmas conotações estão presentes no texto hermiliano, como respaldo da carnavalização que engloba obscenidades, pornografias, como modalidades de "articulações do ser", visões de mundo "enfeitiçadas, satanizadas, encantadas, paganizadas” (IANNI, 1986, p.15). O imaginário hermiliano capta a magia do que está nos contos impregnando o texto, de onde emergem a irreverência, a crítica, a sátira, o humor, o riso e outros, como um estilo de ver o mundo e um estilo de pensamento, que vão além de um estilo de criação artística, numa literatura carnavalizada (posteriormente será discutido), que representa uma vertente de sua ficção, que se mantém receptiva à inventiva do povo e a expande, destacando as variadas modalidades diluídas no contexto de sua literatura.

Apresento o texto 0 arrevesado amor de Pirangi e Donzela ou o Morcego da meia-noite de (GEP, p.32-45). Como analisar este texto? Utilizo os construtos sobre o realismo mágico e me detenho nos aspectos sonoros e outros aspectos linguísticos que se encaminham para o estilo, o que leva à significância do texto, aproximado ainda a aspectos semióticos (SANTAELLA, 1996) e, também, ao plano intertextual (GENETTE, 1982).

As personagens são retiradas do mundo, num espaço/tempo identificados. Donzela e Pirangi vivem um amor, sem que este precise quem é sua companheira, uma louca que vive ao léu, situação identificada apenas no final do texto. A magia, patenteando-se através da linguagem, esteia o clima irreal, em que a negação do que é afirmado se esbate no jogo aliterativo e os sons palatais, misturados com os sons alveolares, determinam o tom fugidio e a fluência de um momento mágico, indefinido: "Tudo porque ela, quem ela?, não mais voltara, mas suas formas que não eram formas, sua bainha aérea, de palpável mesmo somente o fluido perfume de jasmim, jazida que jaz no jazigo, no jogo jacente, já (GEP, p.40). 
Na descrição do nascimento, presentificam-se variadas conotações do realismo mágico, em que a camada sinestésica enfoca um campo imagético fugaz e as sensações despertadas vigem tão rapidamente que não atingem o espaço da consciência, vivenciadas que são como experiências místicas, de uma metáfora do inverossímil, de ordem sobrenatural, situação em que de um ponto de vista semiótico o texto se desdobra em semioses, apresentando "as ferramentas necessárias para a leitura das práticas de linguagem desde as mais simples até as mais complexas" (SANTAELLA, 1996, p.79):

[...] enquanto o corpo de Donzela se abria e começava o Nascimento e de tudo o quanto os olhos atônitos das comadres e dos compadres viram não restou lembrança, caído no esquecimento maior amnésia, porque viram e não se lembraram do dossel em veludo púrpura e franjas de ouro [...] (GEP, p. 43).

Borba Filho é um maestro desta orquestração interna do seu material linguístico. Parodiando Cal (1981), quando se referia a Eça de Queiroz, eu introduzo um intertexto bíblico nos moldes do livro do Apocalipse (Apo, 12, 1-12) para justificar a orquestração:

[franjas de ouro] sustentadas por quatro rechonchudos querubins, um anjo ao lado tocando uma corneta longa que brilhava mais do que o sol, além de uma multidão de anjos e arcanjos que cantavam com vozes seráficas, Donzela na cama azul parindo um pajem louro que, mal nascido, [...] (GEP, p.44).

O autor, sem dúvida tem uma propensão natural para trabalhar a matéria verbal, retirando da massa sonora todos os efeitos expressivos, adequados ao registro discursivo de sua ficção, mormente quando traz à tona uma linguagem carnavalizada, que se manifesta pelo tom 
obsceno, misturando o sagrado e o profano, de onde flui um discurso escatológico, culminando com uma situação inusitada, quando se apresenta um intertexto da oralidade. Arremato com Barthes (1988, p.77): "E é isto o intertexto: a impossibilidade de viver fora do texto infinito - quer este texto seja Proust, ou o jornal diário, ou o écran da televisão: o livro faz o sentido, o sentido faz a vida", quando acrescento, também, o texto que está na oralidade, do qual o narrador sugere variados efeitos: "[um pajem louro que, mal nascido] foi levado pela mão por um sujeito do mais piche, às gargalhadas, aos pulos, aos peidos; os querubins, os anjos e os arcanjos paparicando a ascensão de Donzela, como um balão, de leve, de longe, ignota [...]" (GEP, p. 44).

Complementando este enfoque, é oportuno lembrar um outro estudioso, que evidencia outros aspectos do realismo mágico: "Talvez não seja mero acaso que nas grandes obras do realismo mágico [...] os personagens são destruídos, varridos da face da Terra, juntamente com o mundo que os cerca" (DACANAL, 1988, p.125).

Este mundo, em Borba Filho, quase sempre tem um teor escatológico e a morte, entre outros fenômenos do mundo empírico, é constante, não importa como se apresente. No fragmento do conto "Cinco traques de velha" (p.105-116), há uma enumeração caótica, resgatando a criação de um universo contraditório, em que o que começa finda sem explicação plausível. É preciso entrar em sintonia com o imaginário do autor. Chama-se a atenção para a simetria estabelecida pela sequência de substantivos, determinados pelo numeral. A representação da realidade se efetua num plano concreto de valor simbólico, sobressaindo o realismo mágico como uma hipérbole, sediada pela escatologia:

[...] esmagaram trinta e cinco crianças, quarenta velhos e velhas, um veterinário, dois agricultores, cinco prefeitos de categoria, vinte cachorros entre raciados e vira-latas, setenta e quatro mendigos [...], cinco soldados e um cabo, um padre e 
vinte e nove beatas, sessenta e quatro donzelas comprovadamente de hímens intactos. E assim como começou, assim findou num estrondoso pipoco que matou baleias na costa da Paraíba. $\mathrm{Na}$ praça, recolhiam-se os mortos e um dos cachorros ressuscitou (GEP, p.115-116).

"Para o autor da ficção alegórica ou simbólica [...] não interessa a descrição do real, [...] também não [interessa] a ação sobre o real. Seu objetivo fundamental é a descoberta do sentido real" (DACANAL, 1988, p.75). Nesta perspectiva de Dacanal, talvez esteja um dos aspectos mais importantes dos contos de Borba Filho, principalmente pela transfiguração do real, o que configura a concepção artística do escritor de Palmares.

O autor respondendo a pergunta sobre se havia influência de sua vida sobre sua obra literária, ele respondeu: "- Claro. Eu fotografo tudo e depois transfiguro-lhes. Melhor caricaturo no bom sentido" (CIRANO; ALMEIDA; MAURÍCIO, 1981, p.54). Complemento a afirmação de Borba Filho com a posição de Ianni (1983, p.104): "Inspirado na visão do mundo do homem do povo, e trabalhando esta ideia com engenho e arte, o escritor desenha a figura em que se revela a caricatura", o que se apresenta como uma técnica usual no autor pernambucano.

Borba Filho, reconhecendo que é preciso saber ver, acata a ideia de que a sua literatura tem implicação com o Nordeste. Confessa que o homem deve ser colocado em primeiro plano e não entende "como os escritores dos dias de hoje (década de 70) se possam alhear de todo o processo social, econômico, religioso, e moral quase sempre em crise" (CIRANO; ALMEIDA; MAURÍCIO, 1981, p.56). Realmente, o Nordeste está presente na obra de Borba Filho, não só como ambientação, mas também como referente, na implantação do projeto literário. Mas o que se destaca é o Homem, localizado num contexto universal, onde está presente o desrespeito à vida, quando se patenteia a opressão, a tortura, a discriminação, a violência, entre outras manifestações contra a dignidade humana. Portanto, mesmo se levando em conta 
depoimentos do autor, conteúdo dos contos, assim como o estilo e captação dos significados pelos leitores, seria prematuro dizer que não se pode falar de uma literatura regionalista.

Este cuidado sobre a menção de regionalismo, segundo Azevedo (1984, p.95), apresenta "controvérsia em torno do que seja regionalismo literário."

Intuo, no entanto, que em Borba Filho, pelo menos de modo consciente, a intenção não é "ressaltar os elementos diferenciais que fazem desta ou daquela região uma unidade cultural" (ALMEIDA, 1981, p.53). Também não capto em seus textos o tom exaltatório da terra ou da gente nordestina ou pernambucana.

Logo, não havendo indícios da dicotomia de uma realidade regional x realidade nacional, posso falar de uma oposição/aproximação entre valores populares e valores eruditos, inculcados pelos temas desenvolvidos e pela voz do narrador que, segundo Almeida (1981, p.194), "exprime[m] sobre toda a narrativa seu modo particular de considerar os fatos e as personagens [...]".

Acontece com Borba Filho, que sabe acomodar o estilo bem ao molde de Jameson para quem, "com um pouco de engenhosidade, o regionalismo crítico poderia ser reajustado a sua posição pósmoderna [...]" (JAMESON, 1997, p.196). Embora este estudioso esteja mais voltado para a arquitetura (nesta obra), é possível adequar o seu pensamento ao literário. De qualquer modo, há diferença entre um regionalismo tradicional e um regionalismo pós-moderno que interfere, por conta da evolução das visões de mundo vigentes, na própria identidade do regional em vigor. A memória está no cerne de uma prática regionalista, em que o passado presentifica os elos mantidos com a cultura. Borba Filho, no entanto, parece estar aquém do futuro, pois nas entrelinhas detecto o seu compromisso com o presente pelo modo como critica a realidade dos fatos, o que o situa no contexto do rizoma, visto por Deleuze e Guattari como um sistema aberto, relacionado a circunstâncias e não a essências (DELEUZE, 1992). Vejo que 
assim se representa em Borba Filho o que se designa como regionalismo, o que não impede de continuarmos a discussão.

Leite (1978) diz ser a personagem regionalista a síntese do meio, o que não se verifica na ficção do escritor de Palmares, pois ele está sempre em contato com seres mitificados, criaturas às vezes retiradas de contos populares, de teatro de marionetes, dos folguedos, ou seja, personagens alegóricas, próprias do plano simbólico. Há, no entanto, aquelas personagens representativas do plano real, principalmente quando o narrador as utiliza com intenção crítica ou de denúncia. Elas, pois, reforçam os outros níveis de personagens. $O$ autor renova a artisticidade de seus contos neste intercâmbio de sua literatura com a cultura popular, aproveitando a cultura nordestina e indo mais além, como acontece quando do aproveitamento de dados do cancioneiro popular e outros. Pode ser exemplificado este contexto com variedades do texto, mas selecionei o conto "O perfumista", da obra Sete dias a cavalo (SDC, p. 97-105).

O autor/narrador inclui na história desenvolvida o discurso retirado do teatro de mamulengos e a persona é "Cheiroso", mamulengueiro pernambucano. O conto, de teor fantástico, encaixa na narrativa a visão crítica do mundo real, através de elementos concretos que dão consistência aos desígnios do imaginário:

[...] um tal de Tiridá afamado pelos mangues do Recife mas na minha freguesia é vivida por VidaTorta cuja função é entortar a vida dos outros [...] e começo minhas pancadarias e singularias neste mundo arrevesado de perna para cima e bunda pro ar... [...]. De Cheiroso nada mais se soube, a diligência do Cabo Luís resultou em vão, só deixou mesmo os bonecos que foram queimados no Pátio do Mercado e a fama do perfumista: amante das flores e dos odores (SDC, p. 99, 100, 105). 
A concepção de mundo do autor de "Sete dias a cavalo" (1975) sobre a arte popular, quando se refere ao teatro, preconiza a fidelidade a valores que ele prioriza, nos quais está presente o Nordeste:

É mantendo-se fiel a nossa comunidade que será fiel à pátria, unindo-se a todos aqueles que procuram a mesma coisa em suas diversas regiões; e é mantendo-se fiel ao Brasil que poderá estender, não servilmente, mas fraternalmente a mão às grandes vozes espirituais que não sentem necessidade de trair a liberdade para servir à justiça (BORBA FILHO, 1970, p. 71).

Há, não se pode negar, um vínculo forte de Borba Filho com o Nordeste. Mas como ele mesmo destaca, há um processo de transregionalização, e em todas as regiões é preciso ser fiel ao Brasil. Valho-me de Deleuze (1992, p.126) para concentrar o pensamento de Borba Filho: "Mas se há nisso toda uma ética, há também uma estética. O estilo, num grande escritor, é sempre também um estilo de vida, de nenhum modo algo pessoal, mas a invenção de uma possibilidade de vida, de um modo de existência."

Complemento com Antonio Candido, falando sobre regionalismo na literatura, quando lembra que o regionalismo foi uma fase necessária que focalizou a realidade, mas hoje não é uma forma privilegiada de expressão literária nacional. Para ele não há sentido nessa fixação no regionalismo e a sua superação é fator de amadurecimento. Mas isto não impede que obras importantes tenham ligação com uma perspectiva regionalista. Refiro-me não apenas ao Nordeste, mas a qualquer região brasileira ou áreas fronteiriças ou mesmo fora de qualquer fronteira brasileira, como os Estados Unidos, os países europeus e mesmo áreas que existem apenas no imaginário, como a obra Jogos Vorazes (2010) em que as áreas espaciais são demarcadas por aquilo que cada região produz, como carvão, artigos de luxo, grafite, diamante, etc. 
Voltando à sequência anterior, Candido menciona uma fase do regionalismo que pode ser designada como super-regionalista conforme já fiz referência. O modelo, para ele, seria Guimarães Rosa, espécie de atuação estilizada que interfere na seleção dos temas, dos assuntos e na elaboração da linguagem (CANDIDO, 1987). Esta seria a esteira de Borba Filho, embora encarada sob outro aspecto, pois este escritor registra em suas narrativas curtas a interpretação da leitura no imaginário popular que funciona como representação da visão de mundo do povo.

Gabuglio também estuda o regionalismo numa abordagem sociológica e chega a uma tentativa de classificação do regionalismo brasileiro, dividindo-o em quatro categorias, consideradas precárias pelo próprio estudioso. Vale a pena averiguar: a) conservadora (corresponde às obras que utilizam o regionalismo como meio de preservação das estruturas existentes); b) denunciante (caracterizase pela qualidade estética da obra e pela instauração da denúncia de situações de miséria, de atraso e de dependência e apela para a transformação das estruturas esclerosadas); c) acomodada (referente às obras preocupadas apenas em exportar o pitoresco e o exótico); d) globalizante ("desembocadura das anteriores") (GABUGLIO, 1979, p.44-46). Esta última categoria é captadora de uma forma poética que espelha e transfigura o mundo objetivo, conservando sua pureza e sua poesia (GABUGLIO, 1979). Sob este aspecto, assim como naquele denunciador, posso situar Borba Filho, com algumas restrições e o faço não para dizer que ele é um regionalista, mas para inseri-lo no contexto de uma ficção que, ao mesmo tempo em que é inovadora, não descarta as suas implicações com o mundo real, objetivo, por ele transfigurado, que possa designar como representação da regionalidade.

Acredito, no entanto, que para Borba Filho o que interessa "é o homem com todas as suas reações internas que podem ter ou não repercussão externa. Nada do homem condicionado pelo meio, mas do homem revoltado" (BORBA FILHO, 1974, p. 9). 


\section{História e discurso na representação do real}

As narrativas curtas hermilianas quase sempre assimiladas da realidade estão ligadas a crises sociais e políticas, o que permite historicizar a sua ficção. São situações transmitidas:

a) por contaminação discursiva: “[...] o Almirante agradecendo à proverbial hospitalidade da gloriosa província, terminando com a frase lapidar que Tamandaré havia tomado emprestada ao seu colega Nélson [...] espera que cada um cumpra o seu dever" (GEP, p. 6);

b) por transferência do discurso ficcional para sintetizar o mundo real: "[...] o discurso do Almirante Pederneira Sobral que comanda o nosso navio-escola, honra da Marinha e do Brasil, exemplo do continente americano [...]" (GEP, p. 12);

c) por invenção, centrada no imaginário: “[...] cada um nasce com a sua sina e há sinas piores, como por exemplo a do fiscal de rendas atrás de aguardenteiros contrabandistas na fresca da madrugada" (GEP, p.33).

Há um amálgama do discurso sobre o povo e do discurso do povo, o que acontece quando do aproveitamento do discurso dos espetáculos populares, entre outros dados da inventiva popular, incluindo o cordel. Tudo isto remete para a explanação de uma cultura que se manifesta diferente da cultura letrada, o que faz sobressair a sensibilidade própria do meio popular: "E as beatas se levantando apressadas, uma massa avançando para o altar, siá Claudina culatrão para trás negrada, quem não tiver compostura eu meto a peia" (GEP, p.110).

$\mathrm{O}$ autor de Palmares compreendeu que "o povo pode ser o portador de valores e isso, tal como ele é, através do seu modo de vida 
particular e das produções concretas da sua cultura numa perspectiva [...] social e essencialmente profana" (MOURALIS, 1992, p.115). Por tudo isso, concluo que há um processo de espacialização dos contos hermilianos, uma vez que a cultura ficcionalizada é representativa do Nordeste, mas o narrador a utiliza como motivo para a introdução de uma "visão de mundo", cujo campo artístico mantém uma relação íntima com problemas sociais de situações em que a arbitrariedade se alastra a passos largos, denegrindo a liberdade do ser humano e o respeito pela vida.

É pertinente, pois, pensar a obra hermiliana fixada na categoria de história na perspectiva apresentada por Todorov (1971, p.211), para quem a obra é "história no sentido em que evoca uma certa realidade, acontecimentos que teriam ocorrido; personagens que desse ponto de vista se confundem com os da vida real", por se verificar que o texto hermiliano respalda a história, sob este ponto de vista. 0 próprio autor comprova que num de seus romances: "muita gente de Palmares se viu e me escreveu cartas e me ameaçou e cortou relações comigo" (CIRANO; ALMEIDA; MAURÍCIO, 1981, p.44).

Mas a história é inseparável do discurso que lhe dá consistência e "o signo da relação atinge aí aquela consistência esboçada nos discursos que prometem a interação social criadora" (MEDINA, 2006, p.23). Neste contexto, o discurso sempre estará vinculado a um enfoque bakhtiniano, pois a ficção hermiliana se caracteriza muitas vezes pela retomada e atualização de outro discurso numa atividade socializada. Discurso, pois, será "entendido como fenômeno social - social em todas as esferas da sua existência e em todos seus momentos - desde a imagem sonora até os extratos semânticos mais abstratos" (BAKHTIN, 2010, p.71).

Por isso, posso dizer que Borba Filho, aliando-se à cultura de resistência, ressalta os tempos difíceis do contexto social, demonstrando que é possível fazer história, fazendo literatura.

O conto "O general está pintando" (GEP, p.97-104), que dá nome ao primeiro volume da trilogia de contos, revela-se como uma metáfora 
do mundo real. o próprio título está naquele âmbito em que o que está dito "não está depois do texto, mas que se inscreve no jogo de linguagem por ele exercido. Que se situa, portanto, antes da significação do real para o qual aponta" (BARBOSA, 1974, p. 11).

O título do conto, pois, expressa um aspecto durativo que no plano da narrativa frisa a continuidade ou duração do processo, da ação que pode se intensificar sempre mais. A ausência do complemento para o verbo pintar estabelece uma brecha para o silêncio, o que dá ao verbo pintar a consistência de um signo em aberto. Isto permite situar Carone:

\begin{abstract}
[...] é preciso especificar que o silêncio resultante deste emudecimento não coincide com passividade [...]; antes ele [o silêncio] se identifica com a inibição voluntária de uma linguagem [...] que possibilite a captação de outra mais plena, ou, de alguma maneira, menos precária (CARONE, 1979, p.89).
\end{abstract}

Na parte inicial do conto "O general está pintando", estar pintando significa que ele vai aparecer. E enquanto sua chegada é aguardada, há todo um aparato bélico, pessoas foram desalojadas, agredidas por um batalhão de soldados, comandados por um sargento prepotente e agressivo: "O Sargento grita qualquer coisa gutural, tem-se a impressão de um buldogue latindo..." (GEP, p.99). A população, submissa ao poder instituído, fica de mãos atadas e o medo se expande entre as pessoas. Por isso, o tema desenvolvendo-se num tempo/espaço exíguos no plano do discurso, amplia-se no plano da narrativa, se a relacionamos com o mundo exterior.

A predominância dos elementos descritivos retarda a narrativa cuja história se desenvolve num pátio de pedras nas proximidades de uma igreja e de um convento que "se recortam contra um azul profundo. $\mathrm{O}$ sol encandeia num pátio de pedras e o ar está parado, nada de balouço nas folhas" (GEP, p.99). 
Borba Filho fez a interligação entre o tempo e espaço e o cronótopo que daí resulta, aos moldes de Bakhtin (2010), faz que o tempo se condense, comprima-se e torne-se artisticamente visível e o espaço reveste-se de sentido, medido com o tempo. Este autor sabe fazer uso adequado do tempo e espaço, conseguindo que a partir do espaço de onde fala o narrador, o tempo seja o marcador de transformações no manejo discursivo do plano da narrativa: "entra uma mulher apergaminhada, sai outra amarelecida, em conversa com os fradinhos que não se deixam ver [...]. O silêncio zune" (p.97-98).

Pelo teor do próprio texto, as personagens que vão aparecendo não contam, como designativas de contestação. E a constatação desse fato se explicita pelo assédio da metáfora, em função da palavra-chave "silêncio". Posso, então, inferir que tenho em mãos um projeto literário comprometido com o momento histórico (tempo de ditadura), captando a sua representatividade pela implicitação de uma crítica velada ao real, acobertada pelo poder sugestivo da metáfora. O silêncio torna-se ainda mais intenso, quando entendido como oposição ao seu contrário, um adquirindo pleno sentido diante do outro, situação em que o contraste se destaca através do plano sonoro da linguagem (profusão de eco, paronomásia, homeoteleuto) quando a metáfora se torna necessária para partilhar do imaginário não só como linguagem mas também como representação de uma visão crítica do mundo real, fonte de motivação para o tema, em que se constata que os sons linguísticos representam o "ruído" do silêncio, foco de resistência à realidade verbalizada:

Coisa de tempo, sem se saber contar, o ruído cresce, bufante, ofegante, veículo pesado subindo uma ladeira paralela àquela pela qual se desce ao pátio do convento. Há uma pausa no arquejo, a máquina trabalhando tranquila no planalto, logo aparece no alto, só os pneus nos paralelepípedos irregulares, o motor desligado do caminhão 
militar, na carroçaria dois bancos: soldados sentados dum e doutro lado, fuzis plantados entre as pernas $[. .$.$] (GEP, p.98).$

Também a semelhança fônica objetiva e intensifica a degradação imposta aos fradinhos, pois ao mesmo tempo em que o medo lhes é incutido, cresce o desrespeito à sua dignidade:

[...] o motor bufa, a fumaça que sai pelo cano de escape envolve os fradinhos em uma nuvem escura, os fradinhos tossem, levantam as batinas e tapam as narinas, sufocam, abanam o rosto com as mãos maceradas enquanto que o caminhão vai atingindo o alto da ladeira e desaparece (GEP, p. 99).

O não silêncio, valorizado pela linguagem, através da exploração dos elementos sonoros e da seleção lexical, em contato com o silêncio, manifestado pelas situações de opressão, encaminha-se para um silêncio mais inibidor, que silencia a voz dos que deveriam falar, no plano do real. E o narrador, arrogando-se o direito de registrar, no cerne da narrativa, o desconforto ante a realidade retomada do mundo real, destaca as palavras do escritor: "pertenço a uma cultura de resistência...". E também em torno da cultura de resistência que Bosi menciona: "A escrita de resistência, a narrativa atravessada pela tensão crítica, mostra, sem retórica nem alarde ideológico, que essa 'vida como ela é' é, quase sempre, o ramerrão da vida plena e digna de ser vivida." (2002, p.130)

Borba Filho utiliza a metáfora para operacionalizar não só o nível estético mas também intensificar a resistência, centrado num vocabulário persistente que conduz os fios de uma literatura contestatória, recurso em que o próprio texto, todo ele já uma metáfora se torna a alegoria de uma situação real indesejada. "Chega-se assim a repensar uma série de termos - significado, significação, estrutura, metáfora, 
diacronia, sincronia, história, etc. - que por sua evidente operacionalidade, persistem no vocabulário da crítica" (BARBOSA, 1974, p.28).

Esta antecipação do que se relaciona à persistência da linguagem, na perspectiva de Barbosa, permite lembrar que "o general está pintando" significando "chamar a atenção para si", correspondendo à sexta página do conto, que vem antecedida de um discurso em que a tônica dominante é o aparato bélico para receber o General, adequando-se, no desenvolvimento da narrativa, a um espaço de tempo de uma semana. Observa-se uma mudança no comportamento do Sargento que, de opressor, torna-se subserviente, pois: "o General apeou-se, pisando firme, olhando em volta, demoradamente, fitando afinal a tela, aprovando tudo com um movimento de cabeça dirigido ao sargento que se babou de gozo numa continência rígida de pedra" (p.102).

O espaço do texto não representa apenas a sua tessitura, mas é um espaço em que se ambienta o narcisismo do "General" que, jactandose de si mesmo, extravasa a sua vaidade, através de gestos estudados. o próprio arranjo da linguagem é vetor para o objetivo do narrador que, infiro, vinga-se do general, para ridicularizá-lo, quando a metáfora avulta o literário esperado:

Finalmente o general empunhou um pincel que, em sua mão, adquiriu a graça de um florete, voltou-se para as janeleiras, ao longe, cumprimentou-as com a cabeça [...], em seguida para a pequena multidão da ladeira da esquerda, mesmo gesto [...], viu os fradinhos, acenou-lhes com a mão livre [...], concentrou-se na tela [...], com a mão esquerda procurou o gim [...], mexeu o líquido com o dedão indicador [...], tomou um gole, voltou a concentrar-se (GEP, p.103).

Mais uma vez o silêncio metaforiza a linguagem, pois "o silêncio era profundo". Silêncio que se manifesta como o não-direito de fazer 
uso da voz, o que se esbate num teor artístico sinestésico, quando a tonalidade de cores, o som do assobio, o movimento das pinceladas na tela convergem para um outro sentido de " o general está pintando". De fato, o general está pintando um quadro, mas perde a inspiração e, para concluí-lo, utiliza-se da força da repressão e da violência, pois um menino morre por ousar transgredir o ritual estabelecido para a pintura do quadro. E, assim, o narrador "materializa a metáfora, através de cuja mediação brota a con-sciência [...] não só de como a comunicação se faz [...] - instante em que a metáfora cria uma realidade" (CARONE, 1979, p.37) e o conto que procura representar uma realidade na qual "o silêncio zune" e "o silêncio era profundo" resgata o real, através da metáfora, que é conivente com a própria morte, destacada pelo escritor para lembrar que, sendo a morte uma forma concreta de silenciar, faz que esse silêncio assuma uma função social nas mãos do narrador, produzindo sentidos que vão da denúncia à contestação, atuando como exemplo de resistência. E a morte, cujo sentido migra para o seu sentido oposto, pode ser vista como um sentido simbólico de valorização da vida.

O silêncio é rompido por um menino que queria passar à força: “quero um padre, é vó que está morrendo, quero um padre, os soldados continham-no com os fuzis, o barulho aumentava, o General estava perdendo seu poder de concentração" (p.104). O menino nem tinha consciência de que o que fazia era um ato heroico, determinado pela cultura, o que lembra Todorov, que diz (1995, p.19): "No heroísmo, a morte tem de fato um valor superior à vida. Só a morte [...] permite atingir o absoluto: sacrificando a vida prova-se que se adora mais o ideal do que a própria vida": “[...] o menino rompeu a barreira, desceu embalado de ladeira abaixo, justo quando estava a dois metros do General a bala alcançou-o nas costas, o jato de sangue esguichou na tela" (p.104).

A poética da violência, uma vez instalada, segue seu ritmo e o narrador, como um condutor de imagens, consegue atingir o ápice de seu desenvolvimento. O General que não conseguia terminar o quadro 
que "estava pintando" porque faltava a cor adequada para o pôr do sol "aproveitou aquele vermelho inesperado para o seu crepúsculo, o sorriso abrindo-se, ausente do corpo e do brado" (p.104).

Há, em "O general está pintando", uma técnica discursiva que destaca a produção artística hermiliana, em que estão inclusos a liberdade e o espírito inventivo do escritor, na recriação e redescoberta do real. Este texto assim como muitos outros da trilogia de contos estão enraizados na configuração sociopolítica em que se apresentam. A literatura hermiliana, reagindo à tirania do mundo real, afirma-a, pois "a trabalha por dentro, levando-a às suas consequências necessárias e ocasionais, lógicas e insólitas, trágicas e grotescas" (IANNI, 1983, p.102), registrando em diferentes modulações a repressão política e as suas consequências de que este texto pode ser modelo, na explanação do medo, da insegurança e do pânico, que envolvem as personagens, como uma recriação de situações de dominação e opressão a que o povo fica submetido em "tempos de ditadura". Tudo se exprime literariamente como dados da experiência do autor, que utiliza os elementos da cultura e, de modo especial, da cultura popular, para veicular uma "visão de mundo" compatível com uma perspectiva que atua como invólucro de uma ideologia vivenciada na prática, como oposição ao poder instalado no mundo real.

Para isso, o autor imprime a sua obra elementos linguísticos, ideias, temas, assuntos, motivos e tons configuradores da cultura do povo. E assim Borba Filho também põe o leitor em contato com um processo reinventivo em termos de inovação escritural, o que lembra Guimarães Rosa, Mário de Andrade, José Cândido de Carvalho, poetas de cordel e autores outros que se destacam pelo cultivo da oralidade, como os textos dos folguedos e espetáculos populares.

A vinculação de Borba Filho ao popular traz a sua marca característica. Introduz elementos teatrais e/ou dramáticos, no sentido em que o narrador retoma os dados do teatro de marionetes ou utiliza personagens do bumba meu boi ou cenas de fandango, respectivamente em textos como "O perfumista" (SDC, p.97-106), "O padre" (AMS, p.78-80), 
"O almirante" (GEP, p.1-13) só para citar textos onde transitam atores; por conseguinte, tudo que faz parte de uma representação. Já os elementos dramáticos têm o sentido de conflitivo ou atritivo e podem ser empregados em referência à prosa de ficção, como aspectos de um texto em que o cômico se mistura ao trágico como acontece no conto "A anunciação" (GEP, p.117-27), entre outros.

Logo, é comum o contato com personagens retiradas de folguedos, como o fandango, o mamulengo e o bumba meu boi, sem deixar elementos que estão fora do texto, selecionados de modo astucioso, o que pode ser captado através de uma leitura atenta, basta que se detenha em "marcha-soldado cabeça de papelão" e quem de vinte passa tanto faz": “[...] e lá vai coisa e loisa e lá vai fumaça e cangirão e rataplão e marcha soldado cabeça de papelão e lá vai méis e lá vai mais e quem dá dez dá vinte quem de vinte passa tanto faz e no gilvaz e é na chincha e é da que incha..." (SDC, p.99).

Emprega neologismos, clichês, valendo-se de um palhaço como personagem, para destacar associações com a realidade, através de um léxico sugestivo como "potência", "picuinhas", "arena": “[...] impertérrita potência no porém sempre nos ditos galantes e nas picuinhas serelepes ao avistar uma dama, ele, o palhaço Jurema chamado, afamado e respeitado com os seus pedaços de mau caminho, mas na arena risada de orelha a orelha" (SDC, p.107).

E aproveita aspectos da linguagem dita proibida, respaldando seus textos com palavrões, calões, gírias, ditos populares e outros recursos próprios da linguagem oral cujo teor afetivo determina a visão crítica: "Fela da puta, se você não abrir o focinho eu lhe meto um ovo quente na boca e costuro com arame" (GEP, p.125). Clichês e regionalismos linguísticos servem de fundo ao uso da linguagem coloquial e popular: "[...] chegando o prato do chambaril-se-não-suar-não-paga com pimenta malagueta e mais Ela e nesse mundo mergulhou Lonico Soldador" (AMS, p.76). Apreende-se um traço marcante da técnica hermiliana, referente ao emprego de um vocabulário, que destaca as áreas do baixo corporal, enfatiza o campo semântico da bebida 
e da comida, tudo convergindo para ressaltar a importância que os aspectos sexual, erótico e sensual assumem na obra deste escritor, exercendo fascínio sobre o próprio autor, que os utiliza como publicidade e propaganda disseminadoras de ideias que situam a sua "visão de mundo":

\begin{abstract}
[...] fornicava com três quatro cinco mulheres, com cada média de três sem tirar de dentro, bebia garrafa sem contas de cerveja Portner, comia repolho e salsicha e mostarda sem parar [...] na festa da cachaça [...] tirando o gosto com torresmos, bundinhas de tanajuras, culhão de boi, miolos, sem parar da manhã à noite (SDC, p.93).
\end{abstract}

Borba Filho falando sobre a posição que o sexo assume em sua literatura, diz que é "a mesma coisa que a liberdade". E acrescenta: "encaro o sexo como uma coisa normal e constante na vida de um homem sadio, coisa que todo mundo pratica, uns mais outros menos e eu pratico muito" (CIRANO; ALMEIDA; MAURÍCIO, 1981, p.54). Fazendo uma avaliação de como a crítica se posiciona em relação ao seu trabalho, focaliza Recife, onde não apareceu nenhum comentário a respeito e reconhece que há preconceitos advindos do fato de ele centralizar o sexo, continuamente, na sua escritura. Lembra que prefere ficar com uma ilustre dama francesa do século XVIII que dizia com muito charme: "A única inconveniência de se ler um livro erótico é que a gente não pode segurá-lo com uma mão” (CIRANO; ALMEIDA; MAURÍCIO, 1981, p.57).

Visto assim, parece que Borba Filho coloca sexo e erotismo no mesmo patamar. É interessante observar que ele, quase sempre, refere-se ao sexo, relacionado a ele próprio, o que permite ao seu leitor, ler as isotopias de natureza sexual e erótica como uma metáfora de si mesmo. "Essa metáfora é a ressurreição da experiência e sua transmutação" (PAZ, 1991, p.19). 
A fusão do sexual, do erótico e do sensual, que num sentido amplo pode funcionar como uma semiose do amor, não descarta a possibilidade de distingui-los, o que permite a abertura de novas perspectivas. A sensualidade, ficando sob o domínio dos sentidos, está numa linha intermediária entre a sexualidade e o erotismo. Borba Filho, manipulando estes dados semióticos do prazer, produz uma arte de ruptura, atuando quase sempre como crítica social, política, religiosa e estética.

Paz (1991, p.71) discutindo a área da sexualidade diz que: "em sua época de ascensão, o capitalismo humilhou e explorou o corpo: agora o converte em anúncio de publicidade" e "a boca e os dentes, o ventre e os seios, o pênis e a vagina [...] se transformaram em slogans deste ou daquele produto", através do poder de fascinação exercido sobre os homens pelo erotismo.

$\mathrm{Na}$ literatura hermiliana, esta esfera fascina o próprio autor que a utiliza como propagadora de ideias que disseminam o seu fazer literário como instigador da criação de um mundo verbal que mantém o leitor prisioneiro de uma linguagem apropriada para despertar sensações variadas. No conto "Os tropeiros do céu" (SDC, p.37-41), o plano do discurso faz que o nível da história se esbata numa linguagem em que o tom de sensualidade explora os sentidos do tato e da gustação:

Jésu tinha prática nas mãos, do corpo dela começou a tirar prazeres com que jamais sonhara, era um banho de mel, uma vontade de subir e de ficar junto, agarrada, sentindo nas entrecoxas o que devia sentir, sabia o que era quando ele a deitou protestou proforma, mas hoje é Sexta-Feira da Paixão e eu não sou Jesus? Falou ele, encastoando-a (SDC, p. 31-32).

Não seria uma tática para instalar um impasse entre o mundo real sob o domínio da hipocrisia e uma literatura que sabia o que propunha para abalar as estruturas de uma sociedade marcada pelas injustiças causadoras do medo e da repressão, vigentes no mundo real? E, assim, 
seria conveniente enveredar pelo menos algumas vezes pelos aspectos lúdicos da linguagem para driblar as expectativas.

O erotismo, sob o enfoque da Paz, funciona como "metáfora da sexualidade" e "não é sexo em bruto, mas transfigurado pela imaginação.". Para este estudioso, também o erotismo "não é sexo, mas sexo social", sendo que "a sexualidade é animal, é uma função natural, enquanto o erotismo se desenvolve na sociedade" (PAZ, 1991, p. 74-75). A ilustração retirada do conto "As meninas do sobrado" (AMS, p.1-15) funde sexualidade, erotismo e sensualidade, o que justifica o raciocínio, na sequência esboçada:

E vai Benedito quis ser apresentado à prendada Adélia e logo na primeira noite, tomando chá pela primeira vez na sua vida, estirou as pernas de satisfação e foi o suficiente para que Adélia visse, bem desenhado na calça estreita, o seu instrumento de trabalho e amor, roliço e comprido, bem feito, coisa que a Viscondessa, com a sua centenária experiência, também vira e admirara e concordava com a sobrinha que um homem daqueles não era pra ficar solteiro se estragando por puteiros e clubes sociais (AMS, p. 10).

Paz (1991, p.82), entre outros argumentos, reconhece que "a nossa época converte a sexualidade em ideologia" e "o erotismo se converte em crítica social e política”, o que recomendo como uma possível leitura da ficção hermiliana. Nesta mesma obra, Paz (1991) aprofunda este tema no capítulo "Cama e mesa" (p.58-82).

Esta prática textual não tem, na literatura brasileira, Hermilo Borba Filho como precursor. Na literatura colonial, está implantada a gênese deste recurso estilístico que é comum na literatura universal de todas as épocas, chamando-se a atenção para a obra de Rabelais, à guisa de ilustração. Borba Filho recebeu a pecha de escritor maldito pela linguagem desabrida e pelos temas desenvolvidos. O estudioso 
de sua obra sabe que, neste autor, estes recursos são o traço peculiar de um projeto literário, que em determinados textos segue um plano linear, em outros se manifesta circularmente, noutros se detém em patamares, com recuos e avanços que atingem, sempre, uma linha demarcatória da criação artística.

Chamo a atenção, ainda, neste autor, para a apreensão do tom poético, com explorações sonoras e fluências rítmicas e rímicas. Recria provérbios, transfigura estereótipos e apela para uma sintaxe vista como desvio da norma vigente. Instala uma variedade vocabular, com fortes raízes populares, sem se descuidar da inserção da linguagem técnica e da linguagem erudita. E este diálogo de linguagens contribui para a detectação de uma literatura que erotiza a percepção do leitor pelas nuanças com que ele se depara, estabelecendo-se deste modo a empatia, desdobrada em sintonia com o autor/leitor que se encontram com "- a palavra com seu tema intacto, a palavra penetrada por uma apreciação segura e categórica, a palavra que realmente significa e é responsável por aquilo que diz" (BAKHTIN, 1992, p. 196).

O leitor, defrontando com o inesperado, tem que se concentrar na palavra que significa:

[...] e foram ao pé do muro, [...] balançando a cabeça com muita delicadeza, iniciaram a escalada [...]. Filogônio encantado batendo palminhas de guiné pra quando papai vier, as cabecinhas já beirando a horizontal pareciam bailarinas obedecendo aos mesmos movimentos, uma precisão, agora se estabeleceriam, era, agora, e deu-se: o hórrido! o horrente! o horrífero! o horrípilo!: doze lagartixas da terra avançaram com presteza e cada uma abocanhou a cabeça de uma lagartixa indiana, mastigando-a, os corpos das pacíficas invasoras caindo do mais alto do muro, os rabos em convulsões de cobras angustiadas [...] (GEP, p.35). 
Percebe-se, no autor da trilogia de contos, a fidelidade a um plano de trabalho que preserva a manutenção da tradição oral e dos valores artísticos que resgatam a cultura popular. E mesmo os dados artísticos que transitam pelos meandros do grotesco ou das situações que constrangem aquele tipo de leitor elitista, capta-se, pelo que está explicito ou pelo que está inferido, a imanência do objetivo proposto, qual seja, priorizar o que é representativo da cultura popular, seguida do destaque da memória coletiva, como preservação da tradição. Talvez por isso, só para referendar, o autor utilize tanta variedade de provérbios e tantas repetições, com variantes que se destacam pela força da contextualização. E por último, a transfiguração da realidade, que põe o leitor em contato com uma literatura comprometida com "os valores do homem.".

É comum deparar-se sempre, em Borba Filho, com um discurso que traz as marcas de um discurso preexistente, o que permite questionar a originalidade do seu texto. É o que Todorov (1979) chama de uma rede de relações entre outros textos. Acato também a opinião de Schneider para quem a originalidade absoluta não existe. Para ele também não é relevante o fato de não ter origem, sendo importante o feito de o autor fundar a sua própria. Afinal "a originalidade é apreciada pelo que virá depois, não em relação às suas fontes” (SCHNEIDER, 1990, p.138). E no autor pernambucano ainda que temas e palavras sejam os mesmos, o conteúdo significativo que o texto assume é diverso. Tomando-se Octavio Paz (1991) como referência para fortalecer o pensamento de Schneider, uma observação se impõe. Paz discute a tradução em sentido literal, para dizer em seguida:

Cada texto é único e, simultaneamente, é a tradução de outro texto. Nenhum texto é inteiramente original, porque a própria linguagem, na sua essência já é uma tradução: primeiro, do mundo verbal e, depois, porque cada signo e cada frase traduzem outro signo e outra frase. Mas esse raciocínio pode ser invertido sem perder 
validade; todos os textos são originais porque cada tradução é diferente. Cada tradução é, até certo ponto, uma invenção e assim constitui um texto único (PAZ, 1991, p.131).

Com efeito, refletindo sobre o texto hermiliano, reconheço que o arranjo do discurso, pela sua singularidade, torna irrelevante este aspecto de originalidade, não importa o que tinha sido apreendido, mas o modo como o novo texto se apresenta. É neste cruzamento de discursos que o texto hermiliano traz a lume a energia de sua expressividade. Por isso, concordo com Ducrot quando diz que o discurso segundo não é um mero relato, porque ele cria uma realidade original: "pelo fato mesmo de dizer que alguma coisa já foi dita, diz-se alguma coisa de novo" (DUCROT, 1987, p.159), pois sei que a mudança de contexto muda o sentido do discurso preexistente, como se observa na utilização de trechos do Bumba meu Boi, em que se ressalta o humor, visto como desenvolvimento de uma atividade crítica, resultante do cômico que, na ótica de Jolles (1976), abarca o gracejo e a zombaria. No fragmento abaixo, o humor prepara um desfecho trágico, que resulta, posteriormente, na morte da personagem:

[...] dormindo ao léu e ao déu, durante o mundéu, voando pro céu, nos ditos e nas pornografias, nos ribombos das gargalhadas e das gaitadas e das piadas, piou, piou, foi a ema minha gente, ou foi a dona da ema, foi o padre, foi o padre com seu sacristão, trepa pra cima de bunda no chão (AMS, p.52). 


\section{O cronótopo em processo}

O texto hermiliano, enquanto história, promove o tempo real, destacando elementos associados ao mundo objetivo, com personagens e ações representativas de tempos presentes ou passados, em um enredo natural ou irreal, com predomínio quase sempre da ironia e do humor, este trabalhado aqui na ótica de Jolles (1976) que vê o humor como uma atividade crítica, abarcando o gracejo e a zombaria. Já a ironia entre muitas possibilidades será trabalhada na esteira de Muecke (1995, p.48): "a ironia é dizer alguma coisa de uma forma que ativa não uma, mas uma série infindável de interpretações subjetivas." É assim mesmo que o narrador hermiliano lida com o artefato verbal, apontado para a moderna teoria e crítica literária:

[...] se em tempo de murici cada qual cuide de si,
em tempo de militar é bom ficar sob a proteção
das armas, os militares através dos subordinados,
cuidando da população, do amor, da religião, do
jogo, da fome, do comportamento e do pensa-
mento da população e todos comungando com
essa ideia [...] (SDC, p.18).

Num discurso recontado ou noutro discurso qualquer, direta ou indiretamente, o tempo se presentifica e, às vezes, funciona com força total, obscurecendo outros elementos literários do arranjo história/ discurso, principalmente se associado à relação de espaço:

Os espectadores da madrugada voltaram às suas ocupações, Evangelista e Creusa apertaram-se mais as mãos, caminharam pelos becos frescos e calmos para a Rua Bela, em casa entraram na cama, se deitaram e durante três dias e três noites se entregaram à doce ocupação do beringote beringote (GEP, p.96). 
Os contos hermilianos apreendem tanto o tempo objetivo, que serve de denominador comum para todas as histórias, como apresentam estados subjetivos quando entram em jogo certos fatores de tempo incomuns, de que fala Mendilow (1972), em que o arranjo da linguagem é ritmado pela passagem temporal: “[...] o dia nascendo e o dia morrendo, a noite surgindo e a noite indo, os dias passando com as noites no meio, e os dois carambolando; chegou o inverno, passou, verão forte, sol e estrela, outra vez as chuvas [...]" (SDC, p.67).

Contos que partem da procura do sentido do amor, do sexo, da morte e da vida, encontraram no tempo o suporte ideal para aclimatar ações teatralizadas, fantasia do real que não ultrapassa a encenação. Este recurso serve de esteio para uma visão crítica da sociedade, uma espécie de semente que busca lançar o germe da mudança que não sói acontecer. Talvez seja por isto que o narrador, em algumas histórias, a braços com "a importância de influir sobre a sociedade" (ROUANET, 1985, p.165), apela para o humor e a sátira, através de personagens do mamulengo:

[...] o mais afamado e corriqueiro de todo este Nordeste velho entubibado pela força da natureza [...] agora vou apresentar a comedinha da minha autoria intitulada provisoriamente porque tudo neste mundo é provisório [...] e começo minhas pancadarias e singularias neste mundo arrevesado de perna pra cima e bunda pro ar [...] (SDC, p.99-100).

Também se vai de encontro a uma realidade temporal em que "o tempo considerado reminiscência perde seu caráter de medida cronológica do passado para apresentar-se como medida de vivência" (ARNS, 1980, p.211): “Ali, na região, todo o tempo, diziam, eram tempos de natais: um dançar, um comer, um caçar, um beber, um dormir, um valsar..." (AMS, p.43). 
Convém destacar também aqueles dados textuais em que há fusão de indícios espaciais e temporais, situações em que o tempo se condensa, comprime-se e torna-se visível de modo artístico, quando o espaço se intensifica e penetra, no movimento do tempo, do enredo e da história. Estes dados constituem uma categoria conteudística formal da literatura e Bakhtin desenvolve este estudo que inclui em ensaios de poética histórica, o que se adéqua muito bem aos textos hermilianos, pois "os índices do tempo transparecem no espaço, e o espaço reveste-se de sentido e é medido com o tempo" (BAKHTIN, 2010c, p.211). Este nível de artisticidade, designado como cronótopo, é um recurso literário que unindo tempo e espaço, estabelece parâmetros significativos no processo do desenvolvimento artístico:

E os anos começaram a correr no casarão todo fechado, houve mudanças políticas, houve-as na associação, aconteceu-las nas modas, nos usos e nos costumes, do casarão elas não saíam e nem de nada tomavam conhecimento, do casarão. Só saíam mesmo ao depois do almoço [...], poucas pessoas transpondo os umbrais da moradia (SDC, p.83-4).

Há traços do tempo/espaço em concordância com um sair de si voltando para si que "sintoniza a palavra com pensamento fluente, espontâneo, reflexivamente encadeado, do personagem" (NUNES, 1988, p.64), através de sensações que não podem ser explicadas, no espaço do ser e do não ser, permeado pelo discurso indireto livre, aflorando um tempo sem marcação, sendo tudo indefinido, no destaque dado ao tom poético:

[...] veio o perfume, é jasmim, falou mesmo, era mais do que jasmim, era perfume de tudo [...] mas sensações assim levam a pensamentos assim; estavam em pé ou deitados, ele por baixo e ela por cima, na terra ou no ar? [...] mas jamais tão bom 
, nem se mexia nem precisava, parecia que era mais tudo na cabeça, quando ela soltou o vagido no ápice ele também foi embalado, ficou muito tempo [...], não era hora de ninguém, era sua, havia apresentado armas com quem não sabia, como se fora! Melhor não especular, que nunca especulara nada em toda a sua vida (GEP, p.39).

O tempo, ficando à margem da atividade cotidiana, sinaliza a visão crítica do narrador que coloca na boca do protagonista: "eu não lhe digo sempre que um dia macaco é gente?" (GEP, p.9).

Também o tempo pode associar-se a um passado histórico, o que possibilita manter a ironia, quando são atualizados elementos preservados pela ideologia dominante. O tempo implícito é determinado pelo discurso, moldado em frases fragmentárias: “[...] ele ouvia alguma coisa, realmente, mas não conseguia ligar aves com penas, era marinha, verdes mares, Henrique Dias, nossa raça, brasilidade, qual cisne branco, navio-escola, integração nacional, defesa das nossas costas, a fina flor, Brasil" (GEP, p.12).

Borba Filho faz jus àquilo que Mendilow (1972) destaca como a obsessão do século XX pelo tempo, quando o próprio espaço é conquistado por ele de onde derivam a técnica e os aspectos estruturais da ficção:

Podia-se consultar qualquer relógio de precisão certa ou se podia deixar de consultar fiando somente no pateque filipe de Filogônio quando ele abria a porta do cartório e eram oito de la matina mesmo sem tirar nem pôr; [...], chegando a tal ponto de perfeição que tudo seu - em horas, minutos, segundos, justeza, limpeza, acerto, colocação - não tinha defeito (GEP, p.19-20).

A marcação detalhada do tempo, que quase sempre se processa linearmente, é comum nas narrativas curtas hermilianas: "Só era 
visto uma vez por ano, precisamente na quarta-feira de cinzas, ao meio dia. [...] Um dia, a cidade agitou-se. Era uma quarta-feira comum, de outubro, pleno verão, quando ele aparece, ao meio-dia, a mesma vestimenta, os mesmos andares." (GEP, p.15-16).

Chama-se mais uma vez a atenção para Mendilow (1972, p.36) para dizer que o autor "deve explorar instrumentos diferentes para incitar a atenção do leitor e inspirar a sua pergunta desembaraçada 'e agora?', 'então o quê?'." Mestre nesses artifícios, Borba Filho é pródigo na manipulação de técnicas que enfatizam a história e o discurso, num delineamento que consegue afetar a sequência discursiva. Neste caso, especificamente, convive o narrador com uma metalinguagem e, afora a crítica ao ato de escrever, brinda o leitor com uma nova técnica, resultante de uma convenção ficcional, sem se descuidar da manipulação do tempo:

[...] neste exato momento passo a relatar os amores do escrivão com Pixita, para ajudar a passar o tempo pelo seu aspecto picaresco e para evitar aquela banalidade literária que diz assim: "Decorrido um ano", o que me faria cair numa chatice beletrística, além de eliminar o suspense da narrativa [...] (GEP, p.27).

\section{Personagens como imagem de vida}

Talvez seja exagero dizer que a personagem mais destacável dos contos hermilianos seja o próprio autor ficcionalizado. Detendo-me nos questionamentos de suas personagens, necessariamente defrontome com a fidelidade do narrador ao projeto literário do autor. Descartando esse enfoque que não pretende ser um juízo de valor, tenho de reconhecer que realmente existe na maioria dos contos uma projeção do escritor em suas personagens. Temas, enredos, assuntos, dados literários e outros aspectos de sua ficção gravitam em torno 
de personagens, transmissoras de uma concepção de mundo, revolucionária no plano literário. Registro as palavras de Silvio Roberto de Oliveira sobre as personagens do conto hermiliano:

Personagens: vivos, vividos, bem caracterizados, falantes, falados, naturais, espontâneos, verdadeiros; gente de verdade, não bonecos estereotipados como se uma câmera precisa digitalizasse amostras de vida diretamente para dentro da mente do leitor (OLIVEIRA, 1994, p. 9).

Dou alguns descontos ao entusiasmo do selecionador dos melhores contos de Borba Filho para trilhar um caminho objetivo. É bom lembrar que este escritor expõe nas suas histórias elementos com os quais convive normalmente, principalmente quando se trata de material humano, no caso, personagens reconhecidamente subjugadas ao poder instituído. Infiro que o autor, para não cair no exagero subjetivo, na seleção do material humano e no tratamento literário que lhe dispensa, foi cioso na sua técnica de lidar com as personas:

[...] conviver com estes tipos, conhecer-lhes a linguagem para nela expressar seus pensamentos, interpretar-lhes as maneiras, reações, de tal forma que elas representem expressões estéticas de memória do artista que ao correr da pena, lhes poderá dar, então, vida e vigor (ARNS, 1980, p.150).

O próprio autor se justifica:

A grosso modo, eu lhe poderia dizer que me situo como um ficcionalista, pelo menos nesta fase de agora começada em 0 general está pintando, passando por Sete dias a Cavalo e continuando com As 
meninas do sobrado [...], repito, situo-me do lado de lá, que quero dizer, do lado do povo, como se ele mesmo escrevesse as minhas histórias (ENTREVISTA, 1974, p.4, informação verbal, grifo nosso).

Enfoco, pois, aspectos relevantes de algumas personagens, para mostrar que elas surgem de tal modo da própria vivência do autor que servem de fluxo para projetar imagens de vida. Não são os caracteres destas personagens que contam, mas o que elas representam.

Almirante Siri, pescador de caranguejo, era também CapitãoGeneral de Fandango e "ensaiava durante todos os sábados do ano para o Ciclo de Natal” (GEP, p. 2), sendo confundido com o Almirante Pederneiras Sobral, da Marinha de Guerra. Através dessa personagem, o narrador aborda problemas sociais, como: a) o preconceito racial: "Jamais pensara que o Almirante Pederneira Sobral fosse negro" (GEP, p.8); b) o latifúndio: "Era dono de uma grande fábrica, de grande latifúndio, de bichos e gente" (GEP, p.5); c) a subserviência: “já sei, já sei, Almirante [...] estou inteiramente às suas ordens” (GEP, p.9).

Por intermédio desta personagem, o autor manifesta o compromisso com a cultura popular, mantida pela tradição e desenvolve um dado importante da sua ficção: o apelo ao sexo: “[...] tinha as mulheres que queria” (GEP, p.2). Por esta personagem, Borba Filho instaura a crítica e a comicidade, conseguindo carnavalizar o tema, embora mantendo o relacionamento com o real, "transfigurado" (para usar um termo hermiliano). Almirante Siri é muito mais que o som de um nome é, posso dizer, a perífrase dos valores contidos no projeto literário deste autor.

Anatol Rosenfeld destaca que "é porém a personagem que com mais nitidez torna patente a ficção, e através dela a camada imaginária se adensa e se cristaliza" (ROSENFELD, 1987, p.21). A cristalização do imaginário, em Borba Filho, sobressai através da valorização da cultura popular, quando a personagem recriada do meio das camadas sociais populares, centraliza os motivos do texto hermiliano. Através 
da personagem Dom, um mágico, o narrador denuncia a forte repressão política, que se instaura em regimes autoritários/ditatoriais, e o faz poeticamente, através de uma imagem que representa a alegoria da morte: "preso como comunista, envultou-se, quer dizer, tornou-se invisível: o resto é lenda" (GEP, p.73)

Também é por esta personagem que se instalam elementos teatralizados do popular com a presença marcante da carnavalização, assim como a implicação de dados circenses, com mágicas e outras atividades movimentadas, de aspectos lúdicos. Manifestam-se marcas intensas de intertextualidade, para introduzir o erotismo, quando o sexo se explicita como crítica à pieguice, aproximando o humor e a ironia:

Deu-se as representações teatrais, com especialidade na Vida Paixão e Morte de Nosso Senhor Jesus Cristo, mesmo fora da Semana Santa [...]. [...] o mágico encantava-a com uma carícia de bico de peito [...] no tilintado do mais abaixo o suspiro veio de chanfro... [...] (GEP, p. 60 et pas.).

O texto acima, apesar dos cortes, apresenta Dom, personagem que viabiliza variadas perspectivas da cosmovisão de Borba Filho. Candido, (1987, p.80), após discorrer sobre personagem, destaca que a sua "organização é elemento decisivo da verdade dos seres fictícios, o princípio que lhes infunde vida, calor, e os faz parecer mais coesos, mais apresentáveis e atuantes do que os próprios seres vivos.”. Por isso, quando se pensa na personagem, pensa-se também no emaranhado de seus problemas, enredados na história "conforme uma certa duração temporal, referida a determinadas condições de ambientes" (CANDIDO, 1987, p.53-54).

Discuto, nesta perspectiva, a personagem Zumba, que funciona como metáfora da resistência passiva, no plano político, espécie de propagador de mudanças, por isto sendo chamado de bolchevista. Aparece, primeiro, no conto "A gravata" (GEP, p.74-80), já com a 
marca da tortura impregnada no seu nome "Zumba-Dentão". Fica-se sabendo que é um ser sociável, pois está numa festa de aniversário. É uma personagem ambígua, pois apesar da evolução das ideias não reage à violência, tal como no conto "A anunciação" (GEP, p.117-127) e no conto "O traidor" (SDC, p.43-53):

Só podem ter sido os bolchevistas. Foi o quanto bastou para que o juiz expedisse de boca a ordem de prisão, e o delegado chamasse o cabo Luís com os seus praças para cumpri-la, o cabo indo direto à Rua da Ponte onde o único intelectual bolchevista da cidade morava com a sua mulher (GEP, p.121).

Para um escritor para quem o compromisso maior é com o homem, Zumba-Dentão é uma personagem que marca a sua literatura de histórias curtas:

\footnotetext{
[...] Zumba-Dentão, assim chamado porque nas centenas de prisões por que passara arrancaram-lhe as unhas e todos os dentes menos o grandão da frente, jamais nada se provando porque coisa nenhuma existia, mas ele pagando por qualquer malfeito impune na cidade [...] (GEP, p.121).
}

Há um crescimento continuo na estrutura dessa personagem, podendo ser tanto uma transposição de modelos como uma simples invenção imaginária, embora submetida sempre a um trabalho de imaginação, com base no princípio subjacente de sua relação com a vida real. 0 narrador procura demonstrar que frente à injustiça institucionalizada, nada pode ser feito:

[...] levou um tapa-olho do Cabo Luís que viu tudo rodar, tombou, caiu, quando se levantou: se mal pergunto, por que motivo?, levou outro que 
achanou o pé da goela [...] calado estava calado ficou [...], no fim da tarde o vate chamou o Cabo Luís e disse arranque, Zum-Dentão abriu a boca, o Cabo chegou com o torquês, houve um suspense, segurou no pé do dente e puxou, quase nem saiu sangue, quase também que nem doeu [...] (GEP, p.122).

Impotente quanto à tortura "uma semana depois era Zumba-semDente para todos os efeitos" (GEP, p.122). Zumba é uma personagem complexa. Aceita passivamente a violência e a tortura, o que, na visão de Zeraffa (1974) vai ao encontro simbólico da personagem, sendo necessário admitir que "a missão de subversão, de contestação, ou mais simplesmente de crítica, de que o autor a encarrega se parece também com a ilusão ou, se preferirmos com o mito (ZERAFFA, 1974, p.45): “Agora estava quieto de seu, havia muito que não se dizia mais bolchevista, [...] a ditadura se prolongava e em tempo de ditadura ninguém conspira, cochicha, trama, é esperar que a ditadura passe e chegue a democracia" (GEP, p.43-44).

É uma personagem que se adéqua aos objetivos do autor: denunciar os desmandos do poder instituído. Zumba resolve candidatar-se a prefeito, por reconhecer que depois de trinta anos a edilidade precisaria de mãos civis. De nada adiantaram os conselhos de sua mulher: "Zumba, você além de analfabeto é bolchevista, além de analfabeto e bolchevista você é popular e popular, segundo mardo, não tem vez com patente, mas ele firme [...]" (GEP, p.45).

Personagem que, no plano do discurso, nos dois contos, significa diferentemente no plano da história, como se fosse uma outra personagem. À semelhança do que pode acontecer no mundo real, esta personagem se expande, embora tudo lhe seja negado pelas condições exteriores.

No conto anterior, era o maior intelectual da cidade, apresentando-se aqui como analfabeto. Zumba, no entanto, não se isola e por 
isto é capaz de criar laços. Foi preso e, apesar do apoio dos amigos, é torturado até a morte, e foi o fato de ser analfabeto que o perdeu, dado este que destaca a crítica ao analfabetismo: "E daí começa a agonia de Zumba-sem-Dente, toda a vida analfabeto gabola, teimando que ninguém precisa saber ler para ser feliz como diziam os que sabiam ler" (GEP, p.52).

Supõe-se que o autor usa esta personagem num e noutro texto, com objetivos determinados, mas, de qualquer modo, fica claro o destaque dado ao nível de degradação a que pode chegar o ser humano, quando tem que enfrentar as estruturas sociopolíticas injustas. E a personagem passa a ser "um instrumento cuja situação central depende exclusivamente da sua aptidão para revelar uma certa problemática do mundo", conforme lição de Lukács (s.d, p.83).

Zumba-sem-Dente enlouquece até que "chamou o Cabo Luís e pediu - 'leia isto pelo amor de Deus e me diga o que o que é"' (GEP, p.52). O narrador leva a personagem ao último nível de degradação: "caindo no titibitate, no útero para sempre" (GEP, p.52). Zumba é caluniado como delator dos amigos que o ajudaram e o jornal A Notícia noticiou que ele teve de ser abatido a tiros porque entrara em luta com a sentinela.

O autor mitifica a sua personagem, que pode ser classificada de redonda, na visão de Forster (1974), pois além de estar sempre em processo de transmutação, atua tragicamente, desvinculando-se de qualquer sentimento relacionado ao humor: "[...] a mulher o enrolou, esfaqueado, sem unhas, um braço partido e cinco costelas quebradas [...]" (p.53). A mitificação da personagem resgata a tradição contida no romanceiro popular: "durante um ano e cinco meses quem quisesse ouvir ouviria, partindo da cadeia, o capim da lagoa/O sereno molhou/ Molhou bem molhado/Molhado ficou" (p.53).

Há, nos contos hermilianos, uma gama variada de personagens que se destacam a partir do hipocorístico, quando o signo linguístico deixa de ser arbitrário e se torna motivado. O significado do nome quase sempre está associado à profissão, o que, neste contexto, ilustra-se 
com nomes das prostitutas. Importante também é lembrar que qualquer personagem que tenha algum destaque no texto, desempenha uma função inserida naqueles aspectos mais destacáveis dos contos do autor. Neste debruçar-se sobre o Homem, o autor, que constrói uma personagem como Zumba, está preparado para perscrutar "a atitude básica diante da Vida e da Morte” (ARNS, 1980, p.141) e assim pairar em nível do aprimoramento que se esboça na literatura que tem por base o compromisso social de mudança.

Voltando às personagens, cito o nome de prostitutas de destaque: Doninha-Cu-de-Pato, a única pessoa que ouviu "o homem-bissexto" falar; Pixita era notória metedeira, mexedeira e bundadeira; Cabeça-de Prata, bexigosa; Zezé-me-Afraganhe, que teve a sua donzelice refeita por Dom; Maria-dá-de-Graça, encomendada para atenuante de empregada; Dorotéia-Rabo-Peludo, de maletinha na mão, Verbena, que provocava grande paixão nos homens; Mária, Maria, Mariá, empresária de prostitutas; Teodósia-Rabo-de-Galinha, prostituta estabelecida por conta própria; Maria do Aritombo, que espalhava a notícia do insucesso de cama dos homens; Madame Lambe-Lambe, dona de bordel; Ana-de-Nós-Todos, Maura-Boca-de-Jasmim, Carminha-Alfenim, Maroca-19, Chuchu-Sarará, cinco companheiras peritas nas peripécias de alcova; Negra-da-Cabeça-de-Escapole; Quiterinha, a suma-quenga; Diana, a de trezentos vestidos e trezentos pares de sapatos; Adelaide Arribaçã, xará de uma madre.

Esta lista exaustiva de nomes objetiva ressaltar um tipo de personagem marginalizado pela sociedade, fato comum nos contos hermilianos. Encerro este tópico, situando Candido, por poder considerar as personagens hermilianas como imagem de vida, funcionando como base de sustentação para suas histórias, personagens para quem "Cada traço adquire sentido em função de outro de tal modo que a verossimilhança, o sentimento da realidade depende, sob este aspecto, da unificação do fragmentário pela organização do contexto" (CANDIDO, 1987, p.79-80). 


\section{O narrador como artesão}

Inicio, enfocando o narrador na perspectiva de Benjamin (2012), tal como ele discute nas considerações sobre a obra de Nicolai Leskov. Isto se justifica pelo fato de nos seus contos, Borba Filho vincular as suas histórias, a uma perspectiva popular, ressaltando a oralidade. Escondendo-se por trás do narrador Borba Filho, senhor de sua matéria, a vida humana, trabalha artesanalmente as suas narrativas, desdobrando a experiência dos outros à sua própria experiência e põe em prática o pensamento de Benjamin (2012), discorrendo sobre o narrador.

Sua trilogia de contos é antecedida de ensaios sobre a arte popular, o que respalda o engajamento de Borba Filho nas lides e cultura do povo, conforme se verifica na bibliografia do autor. Por isto, depara-se com figuras ingênuas, próprias de figuras que se expandam a fim de que o espaço, nela, transformado em linguagem, atinja seus objetivos (GENETTE, 1972).

Manifesta-se a simpatia do autor pelos desprivilegiados, o que muitas vezes resulta em momentos poéticos, como no conto "Ladrão de cavalo" (AMS, p.39-40). Borba Filho, nos seus contos, está enraizado no povo, por isto prepara o seu narrador para fixar-se no povo, de tal modo que possa influenciar a personagem na representação de tudo aquilo que está ligado ao modo de vida popular, o que é possível, pois neste contexto, segundo Benjamin (2012, p.231): "O grande narrador tem sempre suas raízes no povo, principalmente nas camadas artesanais."

O narrador introduz a história: "Parda, disse e repetiu: Parda na insistência do poder da força e dor da virola. Parda de preferência, não de lua nem de estrelas, nem toda escura, parda." (AMS, p.39). 0 narrador emudece e a persona assume a narrativa, desenvolvendo um fluxo de consciência, que atua como uma memória de si, pois ao mesmo tempo em que discute os fatos, constituindo uma identidade como "ladrão de cavalo", vai repassando as peripécias por que passa, 
em suas atividades, incluindo esta leitura em que denuncia a violência e tortura, o que, segundo Foucault (2004), são suportes de lembranças que funcionam como exercícios de memória, rememorações de coisas já vividas.

Esta personagem narrando-se a si mesma faz que "Toda uma elaboração de si e por si é necessária para estas tarefas que serão realizadas tanto melhor na medida em que não se esteja identificado de modo ostentatório com as marcas do poder" (FOUCAULT, 1985, p.97). Este narrador de primeira pessoa, desenvolvendo a escrita de si nos moldes de um discurso indireto livre, se permeado pelo narrador de Benjamin (2012), nos leva a dizer que "O narrador retira o que ele conta da experiência: de sua própria experiência ou da relatada por outros" (BENJAMIN, 2012, p.217).

No último parágrafo do conto, o narrador retoma a narrativa, conseguindo manter o clima de irrealidade desenvolvido pela persona. 0 plano simbólico norteia todo o discurso. As margens fluidas e instigantes funcionam como simbologia da morte:

Atravessou a noite na virola e quando a madrugada chegou, luz baça de inverno, de corpo estendido na pedra fria, só se lembrava do galo branco e só sentia o suor do tordilho, o leve suor que levava a prados e campinas, a capim-gordura, a melão-de-são-caetano, a rio. Ergueu-se a custo, quebrado, toda uma dor, viu a porta aberta e na calçada, amarrado à arvore, o tordilho. Leve, cavalgou-o: galoparam, cavalo e cavaleiro para o nunca (AMS, p.40).

Já em "Legenda de natal" (AMS, p.43-45), o narrador repassa para o leitor uma história que ouviu contar, provavelmente de um caçador: "Ali, na região, todo tempo, diziam, eram tempos de natais." A partir dessa introdução, o narrador desenvolve uma história em torno de 
uma cutia, um mamífero roedor que se alimenta de frutos e sementes caídos das árvores.

O discurso, à moda oral, com ausência quase total de pontuação, é engendrado por frases centopeicas. O campo do imaginário, desvinculado do real, é multifacetado pelo narrador que introduz a cutia no plano simbólico, de onde emana uma aura do sagrado, desdobrável numa visão epifânica do acontecimento: "E por via das dúvidas ali na região não mais se caçou cutia em tempos de natais" (AMS, p. 45). Após a leitura do texto, sugiro que devemos concordar com Benjamin (2012, p.214): “[...] entre as narrativas escritas, as melhores são as que menos se distinguem das histórias orais contadas pelos inúmeros caçadores anônimos".

A cutia apareceu com um chapéu nos dentes numa tarde de muita movimentação, "no terreiro da casa grande" se adentrou e colocou o chapéu com a copa para cima e voltou-se e sumiu na mata e o povo procurou em derredor em torno de cinquenta léguas uma pessoa que havia perdido o chapéu. Após várias vezes visto o chapéu num homem de olhos azuis e cabelos louros, que chegara a pescar com o grupo e "foram peixes e mais peixes para a fome de todos os moradores e sem se salgarem não apodreceram" (AMS, p.44). O chapéu, miticizado, mudou o comportamento das pessoas e ficou decidido que a cada ano o chapéu seria levado em procissão para passar um ano em cada engenho. Procissão com: "fogos, bomba, reco-reco, pífanos, música de saracotico com negaças e volteios, todos na dança e na alegria, nos comes-e-bebes [...]" (AMS, p.44). Logo, o escritor une sua memória à memória passageira do narrador e centraliza a cultura popular no cerne da narrativa e, como Leskov, trabalha a matéria-prima da experiência e ouso dizer com Benjamin (2012, p. 214): "a experiência que passa de boca em boca é a fonte a que recorrem todos os narradores", tal como Borba Filho, travestido de narrador.

Outras histórias comprovam que Borba Filho consegue despertar o interesse pelos seus contos, ao mesmo tempo em que desenvolve no narrador a disposição constante para designar efeitos da cultura 
popular, resultante do campo da memória e da tradição, influenciando o narrador para demonstrar que a oralidade é trabalhada, enquanto as histórias são contadas de novo. Trago Zumthor (1993) para complementar a atuação do narrador na ótica de Benjamin (2012) ao mesmo tempo em que procuro realçar o vigor da cultura, trabalhada literariamente e destacar "Lugar e tempo da performance [que] podem ser determinados pela ocasião social em que ela se produz" (ZUMTHOR, 1993, p.254), segundo a técnica desenvolvida por Borba Filho: “De golpe, assim de repente, o menino não se lembrava de quando a história começou, mas do tempo sim [...]. Só muito tempo depois, quando o menino já era contador de estórias entre a idade de homem e a idade de velho [...]" (AMS, p.48-49).

A última das "10 histórias de Zona-da-Mata" está no âmbito do predomínio da tradição oral, com aproximação da técnica utilizada pela literatura de folhetos, como Leandro Gomes de Barros em Peleja de Manoel Riachão com o diabo (s.d.):

\author{
Esta história que escrevi \\ Não foi por mim inventada: \\ Um velho daquela época \\ Tem ainda decorada. \\ Minhas aqui só são as rimas \\ Exceto elas mais nada!
}

Recorre-se mais uma vez a Benjamin (2012, p.21) no sentido em que a história: “apresenta a melhor imagem do processo pelo qual a narrativa perfeita vem à luz do dia, como coroamento das várias camadas constituídas pelas narrações sucessivas": "o pai do avô contava que o Boi aparecera pela primeira vez lá pelos idos de setecentos [...]" (AMS, p.57). Posteriormente, o narrador retoma o início da história: "Esta foi a primeira das histórias de Boi contadas pelo pai do avô" (AMS, p.58). O texto entremeado de elementos do Bumba-meuBoi, está duplamente ligado ao popular, pois está presente também 
num fragmento de acalanto característico do Nordeste, em que o intertexto desconstrói o discurso: "Boi, Boi, Boi, Boi da cara preta, o menino vai pegá-lo, não tem medo de careta.”. Este recurso mistifica o mito, isto é, torna-o alegórico, pois o narrador, neste contexto, em sendo onisciente, procura também convencer o leitor de que o que diz é verdade, pois "Leonardo das Benevides da Souza Paiva não tinha outro fito na vida, verdade: o Boi [...]” (AMS, p.59).

Nestas "10 histórias da Zona-da-Mata", o narrador estabelece a relação com o ouvinte interessado em conservar o que foi narrado. Nas "10 histórias naturais", que representam também a técnica narrativa da maioria dos contos, o narrador já não pode ser visto sob a perspectiva benjaminiana, uma vez que os contos coligidos representam o imaginário do autor, com base em dados da experiência do mundo empírico e não em histórias ouvidas oralmente do cancioneiro popular. O próprio autor, disfarçado em narrador, encabeça estes contos, o que na visão de Hohlfeldt (1981, p.174) se manifesta:

[...] com textos monoblocos, quase monolíticos,
sem qualquer troca de parágrafo de que se ausenta
o narrador que criaria a ambiguidade narrativa,
alcançando-lhes, por isto mesmo, força de pre-
sentificação, de naturalidade, o que constitui uma
maneira específica de narrar [...]. (HOHLFELDT,
1981, p.174).

Em Borba Filho, destaca-se o seu compromisso com os marginalizados, o que classifico como fidelidade a uma literatura a serviço da vida. É interessante destacar, na esteira de Eco (1993), que o testemunho do autor empírico, embora na prática às vezes perca o controle do que se escreveu é importante, não só para compreender o texto, mas, principalmente, para entender o processo criativo, quando "certas soluções textuais surgem por acaso, ou em decorrência de mecanismos inconscientes" (ECO, 1993, p. 100), como, por exemplo, a seleção do vocabulário, a estrutura sintática, a retomada de discursos 
preexistentes, a utilização de uma linguagem sensorial, entre outras possibilidades. Nas pegadas de Eco, pode-se introduzir a noção de um autor-modelo que atua e se revela para estimular a imaginação, sendo a voz ou a estratégia que confunde o autor empírico (ECO, 1994). O autor-modelo guia o leitor empírico para torná-lo um leitor-modelo. O texto que selecionei para estudo demonstra que o discurso também faz parte da estratégia do autor-modelo e de certo modo é o discurso, não a história, que faz o autor-modelo reagir motivado por técnicas várias que abrangem os planos da linguagem, com destaque para os aspectos sonoros.

No conto "A prostituta" (AMS, p.63-65), o autor inicia o texto com um narrador de primeira pessoa, que sabe tudo sobre a personagem. Na visão do autor empírico, Quiterinha é o protótipo de mulher-objeto. Já o autor-modelo encaminha o discurso de tal modo que a personagem é tratada afetivamente. O leitor empírico pode ver a prostituta centrada no topo da hierarquia, mas o leitor-modelo capta, entre o significado, os significados secretos, o que pode ser feito através de inferências. Eco recusa a ideia de que um texto possa ter qualquer sentido, mas acredita que um texto pode ter muitos sentidos, o que também acato enquanto leitora empírica e enquanto leitora-modelo de Borba Filho (ECO, 1994).

O efeito das metáforas comprova que falar da morte é destacar a vida e incita dizer que o arranjo da linguagem desencadeia uma série de contradições. Em "Quiterinha, a suma-quenga", o neologismo provocado pelo deslocamento do adjetivo resulta no composto por justaposição, o que, no plano sonoro permite três planos de significação: /a suma-quenga/, /assuma, quenga/ e /ah! suma, quenga/, estratégias textuais que envolvem o autor empírico, o autor-modelo, o leitor empírico, o leitor-modelo e o discurso, fato comum na escritura hermiliana. Quiterinha, homenageada na morte, destaca que para além da intenção do autor, existe a intenção do texto $(E C O, 1993)$ que apresenta diferentes atitudes ante a morte: a) morte como separação definitiva: "Quiterinha passara-se, com armas e bagagens, se fora de 
vez"; b) morte como Senhora da vida: “[...] Quiterinha de quem só se via a cara branca, toda arrodeada de flores, as carpideiras não carpiam mais, eram os seresteiros que cantavam serestas, nos gemidos dos bandolins e dos cavaquinhos".

Processa-se, pois, através da literatura, uma função dialética entre o autor e público (leia-se o último termo como leitor), embora ao se analisar a obra como realidade autônoma, possa-se reconhecer que "autor-obra-público" são coexistentes e contemporâneos na análise (RICCIARDI, 1971). Borba Filho, enquanto autor-empírico, mergulha a sua obra no momento histórico em que a origina e o faz não só em função do momento político, implícito em seus contos, mas vai mais além, na captação de motivos outros como acontece em textos em que estão explícitas semioses do sexo, o que faz lembrar a época da revolução sexual. Isso determina também o compromisso com a realidade cotidiana e desmitifica ainda o papel do intelectual em relação à sociedade (RICCIARDI, 1971).

A linguagem, de teor poético, mantém o ritmo da narrativa: "No centro da zona, no coração da zona, da zona açucareira e nos arredores de não sei bem quantas léguas [...]" (GEP, p.63). 0 narrador apresenta a personagem: "[...] a morta Quiterinha, dona dos penachos e dos gargarejos das noites alegres da bebida corrida e do amor doído, que amor de puta sempre dói talvez até pior [...]" (p.63).

O juízo de valor se intensifica na parte final da história: “[...] todos juntos no enterro de Quiterinha na tarde quieta de verão, com cigarras e vento brando, em volta dela os mortos e os vivos, que merecedente ela era pelos prazeres dados e vividos" (GEP, p.65).

Mas há situações, o que é comum, em que o narrador de terceira pessoa é onisciente e recebe auxílio do autor implícito que projeta sobre ele:

[...] certas atitudes ideológicas, éticas, culturais, etc, que perfilha, o que não quer dizer que o faça de forma direta e linear, mas eventualmente 
cultivando estratégias ajustadas à representação artística dessas atitudes: ironia, aproximação parcial, construção de um alter ego [...] (REIS; LOPES, 1988, p.62).

"E vai estavam ali os cinco, fechados, bebericando café e gasosa, nada de bebida forte para não embotar as faculdades astuciosas, mal se viam por entre a fumaça, todos na sua habilidade pessoal, no esforço, esbarrando jogo de empate será, talvez, por que não?” (GEP, p.133).

O narrador age quase sempre de modo sorrateiro, nesta troca de posição com o autor que está sempre à espreita de seus lances. Também utiliza as personagens para auxiliá-lo no desenvolvimento da história, o que explicita o tipo de discurso que melhor se adapta ao enunciado:

O fiscal olhou Neco Graveto que estava rindo sem dar a mínima, esperou um gesto dele, mas tudo o que ele fez foi torcer as rédeas do cavalo e retomar a viagem, sem nem mesmo olhar para trás, o Fiscal voltado na sela vendo ainda por muito tempo os corpos estirados na campina (SDC, p.129).

\section{A topografia verbal}

Analisando a linguagem hermiliana, como um estilo que destaca as suas narrativas curtas, convém lembrar que, sendo a linguagem "obra contínua e comum de todos os membros do grupo social" (LEROY, 1977, p.174), cabe ao autor impingir-lhe certas inovações, que poderão ou não ser aceitas pelos membros da comunidade linguística. A linguagem comum utilizada pelo escritor poderá alcançar efeitos estéticos através de combinações fônicas, morfológicas, sintáticas e semânticas, que suscitam a representação desejada. Nem sempre o 
autor consegue atingir o seu objetivo em relação a leitores, cujo grau de compreensão não interage com a perspectiva artística do escritor.

E mesmo que se diga que "a matéria básica do escritor é a linguagem do seu grupo social” (LEROY, 1977, p.175), não foi difícil para Borba Filho, de formação acadêmica acentuada, ligado que era às camadas sociais intelectualizadas, desenvolver seu projeto artístico, pois manteve contato com pessoas simples desde sua infância e adolescência. Conhecedor da cultura popular e adepto dela, canaliza para sua arte a "visão de mundo" popular e o faz não tanto pelos temas que desenvolve, mas principalmente pela linguagem que dá consistência à sua expressão literária.

Essa apreensão do popular pelo discurso literário de Borba Filho é o lastro que prevê a instauração de uma linguagem mais revolucionária que subversiva, pela destreza com que recria sentidos e instaura a sua concepção de mundo. A sua linguagem, que se enquadra em Bakhtin, diz ser a situação social que vai determinar o tipo de enunciação que servirá para exprimir o real que pode ser a fome, a violência, a opressão, a tortura, "a partir das direções inflexivas da experiência” (BAKHTIN, 1992, p.116). Cada situação é única em cada texto. Examino alguns dados ligados ao tema da morte para comprovar como o escritor consegue usar a metáfora exata, a imagem precisa, adaptada à situação contextual. Selecionei o texto "O portador" (SDC, p.69-78) porque ilustra todos os elementos justificadores da explanação feita.

O portador, de nome Belisário, leva a morte a quem dele se aproxima. Deixo de lado o aspecto supersticioso, próprio da crendice popular de alguém poder provocar a morte das pessoas, animais e plantas só pela força do olhar, para averiguar os dados recriados pela linguagem na detectação da morte. Ao mesmo tempo, convém ser observado o modo como o narrador manipula "uma diversidade social de linguagens, organizadas artisticamente, às vezes de línguas e de vozes individuais" (BAKHTIN, 2010a, p.74). 
O narrador traduz a visão popular:

[...] encontrou Belisário [...] deu-lhe uma dor lá nela, caiu, estrebuchou e pronto. [...] topou com Belisário [...] foi só desviar a vista, escorregar e timbungar sem saber nadar desapareceu. [...] o bilhete que Belisário mandara a seu Cleofas almocreve e foi seu Cleofas lê-lo e amanhecer-olhando-o-dedo-grande-do-pé; a tudo os descrentes respondendo a palavra coincidência (SDC, p.69).

O "portador" está a serviço do Coronel Tancredo Paes das Neves Sobrinho que, quando queria se ver livre de um desafeto, "era só mandar Belisário dar dois dedos de prosa e o de cujus abecava a damanegra sem mais nem menos" (p.70). O discurso muda de tom, com vozes anônimas, em que o narrador investe na inovação da pontuação e emprego da maiúscula: "[...] porque então já não morreu todo mundo que com ele se encontrou? ao que os crentes contrapunham: Não morreu, mas vai morrer; e Morrer todo mundo morre; mas não antes do tempo" (p.70).

o narrador se vale da metalinguagem, no manejo da crítica, quando introduz vozes individuais, linguagem adaptada à condição social dos falantes:

As autoridades não se dignavam sequer a tomar conhecimento das queixas porque afinal de contas Belisário matava se matava, sem arma de fogo ou faca, veneno ou murro, nada, só com o olhar?, ora, nesta não caio eu, afirmava o prefeito; Passou, olhou, viu, morreu?, ria o juiz, não me digam, e o promotor: Só de longe, assim, sem mais nem menos, coalha o sangue?, e o delegado: Que é que vocês querem que eu faça?, tudo isto são metáforas e eu só lido com metásteses, ao que todos ficavam no mesmo e terminavam concordando com ele (SDC, p.70). 
Belisário, conhecedor do seu potencial, transforma em ato a sua força maléfica, o que lhe valeu o apelido de Homem da Foice: "[...] que gente mais frouxa, está com medo de entrar no rol dos bons" (p.70). Em seguida, uma voz não identificada se vale da "linguagem proibida" para designar a morte: "Fechou o furico? É, fechou" (p.71). A linguagem popular cruza-se entre narrador e personagem: "Belisário apareceu comendo uns brebotes [...] a gaitada dobrando, eita que a merda vai virá boné e nisto passou um tal de Pulquerio [...] e dito e feito, o homem não andou mais nem dez passos, torceu sobre o eixo, rodopiou, caiu, desocupou o beco (p.72)."

Ainda para designar a morte, o narrador recorre a metáforas: "voltara numa rede, o bigode atravessado na garganta [...] morrera na vez que the coubera, [...], se afolozasse" (p.73). A imagem se torna significativa quando encaixotada nos labirintos do texto a que pertence, como na enumeração, abaixo, em que o predomínio da sensação auditiva, no plano da expressão, determina o silêncio, no plano de conteúdo, quando se pode dizer que o contexto define as conotações. A terra silencia e detém os elementos constitutivos da vida até chegar ao "vazio oco", ao nada. A seleção vocabular, utilizando vocábulos expressivos (marulhar, farfalhar, zumbido), sugere a ideia do que se quer designar, como a presença da vida, neutralizada por antecipação; o arranjo sintático, estabelecendo paralelismos, determina o ritmo e gera a harmonia imitativa, representativa dos sons da natureza; a substantivação dos verbos focaliza uma visão dinâmica, num processo em ação. As coliterações das oclusivas /p/, /b/, /t/, /d/, /k/,/g/ destacam fonemas homorgânicos que sugerem a ideia de cessamento. Já as fricativas /f/,/v/,/s/, /z/ sugerem sons de certa duração, bem como os fenômenos que acarretam como a imitação do sopro ou o fluir de algo que se esvai. Os sons vocálicos, notadamente os de ressonância nasal, exprimem prolongamento, sugerindo persistência, no que é fortalecido pelo som do /a/ que denota ampliação. Por último, tudo se cala, restando o nada. Neste texto em que se imbricam todos os sons da linguagem, Borba Filho estrutura um jogo de tensão e 
distensão, com características afetivas que destacam o silêncio, que se torna fisicamente perceptível, a ênfase sendo provocada no final do período com a utilização da expressão "vazio oco": "Foi como se a terra inteira silenciasse de repente, detendo o vento, o marulhar das águas, o farfalhar dos coqueiros, a conversa das formigas, o canto dos passarinhos, as vozes dos animais, o zumbido do silêncio, somente o vazio oco" (p.75).

0 assédio das imagens neste conto (fato normal nos contos hermilianos) determina o nível de ambiguidade do discurso e a imagem fantástica que encaminha o desfecho, explora a hipérbole em que se estrutura o grotesco, o maravilhoso, entre outras categorias. A morte, que é uma coisa séria, vem sempre antecedida do riso. E nesta apreensão barroca de um real que só é verdadeiro enquanto ficção, a magia da linguagem induz que: "O discurso do escritor produz efeito de realidade porque utiliza ao máximo o poder de fascinação pela imagem [...]" (MACHEREY, 1971, p.61). E é justamente este intercâmbio da linguagem com o mundo real que permite ao autor deste conto conservar um clima de fascinação que, mesmo saturado da exploração imagística, não estabelece em nenhum momento algum indício de monotonia. $\mathrm{E}$ assim a linguagem é sempre nova, "não pela sua forma material de existência" (MACHEREY, 1971, p. 57), mas pelo poder evocativo e pelo fato de não ser aferido por nenhum padrão. Observa-se o efeito do gerúndio do qual o autor extrai valor estético no desligamento da noção de atos ou fatos, que estabelecem um sentido de continuidade, na implantação do tom descrito. A linguagem de teor auditivo estabelece a combinação dos sons, sem o seu comunicado figurativo, no sentido de reforçar a sensação da coisa mencionada, recurso atuante no estilo hermiliano, como é comum em Eça de Queiroz (CAL, 1981):

E Belisário disparou na gaitada mais violenta que se possa imaginar, uma gaitada maior que o fragor das cachoeiras e o ribombar dos trovões, uma gaitada superior a tiros de cem canhões ao mesmo 
tempo [...], abalando os alicerces da igreja matriz cujo sino começou a bimbalhar, os soldados as putas e os jogadores dentro de casa batendo queixo, a gaitada entrando pelos olhos e ouvidos, pelo degas, pelo meato urinário, alojando-se no estômago e sacolejando o ente [...], a gaitada subia e descia em faixas, acumulando-se, ribombando, os peixes boiaram mortos e as galinhas voaram pairando no ar, os bois mugiram e deitaram-se agoniados, os cavalos dispararam [...] (SDC, 1981, p.57-58).

Após parar a risada, morrem Belisário e o coveiro. E nem um guindaste com capacidade para milhões de toneladas conseguiu levantar o morto para colocar no caixão, e "quando o dia amanheceu, haviam nascido margaridas nos olhos, nos ouvidos, nas ventas e na boca de Belisário [...]" (SDC, p.76).

O clima de maravilhoso se dá, ainda, quando "oito meninos e oito meninas com a farda do Colégio Nossa Senhora de Lurdes, agarraram Belisário, colocaram-no no esquife, fecharam, pegaram nas alças e o conduziram para o cemitério [...]" (SDC, p.77). Efetiva-se o halo do irreal na aproximação de seres díspares ao pé da cova:

[...] um gato de olho de fogo miando e querendo dentar um urubu de cabeça encarnada, aparecendo um negro magro, alto, de canela fina, ainda não nunca visto naqueles pagos, afastou os notáveis com a maior cerimônia, afastou as crianças com toda a delicadeza, já o povo com uma certa brutalidade, e falou: $\mathrm{O}$ ente não pode ser enterrado (SDC, 1981p.77).

Depreende-se, a partir da linguagem, que o teor de realismo mágico, ["nesta hora levantou-se um pé de vento descomunal naquele mesmo momento foi Belisário carregado, sorvetido, de nada ficou"] 
(SDC, p.77), é substituído por elementos concretos do mundo objetivo em que "todas as palavras e formas são povoadas de intenção" (BAKHTIN, 2010, p.100). Observe-se também a visão crítica com base em dados do real: "[...] os notáveis voltaram às suas memórias, até que quinze anos depois morreu a primeira pessoa de velhice: o Coronel Tancredo Paes das Neves Sobrinho" (SDC, p.77).

E assim termina a história de "O portador", ao mesmo tempo em que se encerra o enfoque sobre a linguagem trabalhada por Borba Filho. Linguagem que, carregada de um conteúdo vivencial, revigora o estilo, por traduzir a concepção de mundo, disseminada pela ótica da cultura popular, o que será desenvolvido no próximo capítulo, no contexto de eixos da cultura, nas memórias de resistência. 